\title{
Monitoring Rock Ptarmigan (Lagopus muta) populations in the Western Aleutian Islands, Alaska
}

\author{
Clait E. Braun ${ }^{1, *}$, William P. Taylor ${ }^{2},{\text { Steven M. } \text { Ebbert }^{3,4} \text {, and Lisa M. Spitler }}^{5}$ \\ ${ }^{1}$ Grouse Inc., 5572 North Ventana Vista Road, Tucson, Arizona 85750 USA \\ ${ }^{2} 12841$ Nora Drive, Anchorage, Alaska 99515 USA \\ ${ }^{3}$ Alaska Maritime National Wildlife Refuge, 95 Sterling Highway, Suite 101, Homer, Alaska 99603 USA \\ ${ }^{4}$ Current Address: P.O. Box 457, Anchor Point, Alaska 99556 USA \\ ${ }^{5}$ Alaska Maritime National Wildlife Refuge, Aleutian Islands Unit, P.O. Box 5251, Adak, Alaska 99546 USA \\ "Corresponding author: sgwtp66@gmail.com
}

Braun, C.E., W.P. Taylor, S.M. Ebbert, and L.M. Spitler. 2019. Monitoring Rock Ptarmigan populations in the Western Aleutian Islands, Alaska. Canadian Field-Naturalist 133(1): 49-55. https:doi.org/10.22621/cfn.v133i1.1948

\begin{abstract}
Knowledge of population fluctuations of Aleutian Islands Rock Ptarmigan (Lagopus muta) is limited because of isolation and access. We reviewed the available but limited data on ptarmigan counts on islands in North America and evaluated the use of point counts to estimate changes in apparent numbers of Rock Ptarmigan on three islands (Adak, Amchitka, and Attu) in the Western Aleutian Islands in Alaska. We developed a standardized protocol to count numbers of Rock Ptarmigan (males and females) seen and/or heard on 5-minute point counts at $0.8 \mathrm{~km}$ intervals along marked global positioning system routes on Adak (2015-2017), Amchitka (2015), and Attu (2015) islands. Apparent densities based on Rock Ptarmigan seen and/or heard at 98 stops on 10 routes varied and were highest (1.9 birds per stop in 2015, 1.4 in 2016, and 1.0 in 2017) on Adak, lower ( 0.4 birds per stop) on Amchitka, and lowest ( 0.0 birds per stop) on Attu in late May-early June 2015. These island populations represent three subspecies and unique conservation units. Continuation of point-count surveys of these three subspecies in future years will provide baseline data over time and lead to a better understanding of any fluctuations in and synchrony among Rock Ptarmigan populations on these islands. This information is necessary for both theoretical (how are ptarmigan breeding populations regulated on islands) and practical reasons (identifying the optimal period for possible translocation to islands where ptarmigan were extirpated by introduced Arctic Fox [Vulpes lagopus]).
\end{abstract}

Key words: Rock Ptarmigan; Lagopus muta; Adak; Amchitka; Attu; Aleutian Islands; point counts; Alaska; USA

\section{Introduction}

Animal population fluctuations have long been of interest (Elton 1924), especially in insular areas that have no obvious corridors or where populations are otherwise isolated. Rock Ptarmigan (Lagopus muta) has a circumpolar distribution in northern latitudes with multiple subspecies: up to 14 in North America alone (AOU 1957; the last time subspecies were listed by the American Ornithologists' Union). Populations of Rock Ptarmigan occupy remote areas and their distribution can be highly fragmented including on islands. Thus, documentation of population fluctuations over time can be difficult. It is important to monitor the status and population changes of species, such as Rock Ptarmigan, and to investigate any underlying factors affecting long-term changes (Pedersen et al. 2005; Tesar et al. 2016). Measuring changes over time can be problematic in isolated areas such as in the Arctic and substantial efforts to learn how to effectively monitor population status of ptarmigan have been made (Pelletier and Krebs 1997; Bart et al. 2011).

There is some evidence that Rock Ptarmigan are cyclic on islands (Iceland; Magnússon et al. 2004), but population trends are poorly documented in North America (Weeden 1965; Cotter 1999; Taylor 2013). Peaks in Rock Ptarmigan cycles may represent a 10 -fold increase from lows as discussed by Holder and Montgomerie (1993: 15), who cited studies in Scotland (Watson 1965) and Canada (Cotter 1991). Grouse cycles may be correlated with changes in their predator numbers or parasites and not only immigration or emigration from the local population (Dobson and Hudson 1992; Hudson et al. 1992; Cattadori et al. 2005).

As many as seven to eight subspecies of Rock Ptarmigan have been described from the Aleutian Archipelago, Alaska (AOU 1957). This number has been condensed into four groups ( $L$. m. evermanni, L. m. townsendi, L. m. atkhensis, and L. m. nelsoni) of which nelsoni also occur on mainland Alaska to

A contribution towards the cost of this publication has been provided by the Thomas Manning Memorial Fund of the Ottawa Field-Naturalists' Club. 
the east (Gibson and Kessel 1997; Montgomerie and Holder 2008). The evermanni subspecies occurs in the Near Islands (Attu and Agattu); townsendi occurs in the Rat Islands, including Amchitka and Kiska islands, while atkhensis occurs in the Andreanof Islands group including Adak, Tanaga to Atka, and possibly other islands. We studied three subspecies (atkhensis, evermanni, and townsendi), all of which are considered endemic groups or unique conservation units (Pruett et al. 2010).

Pelletier and Krebs (1997) tested line transect methods to estimate densities of breeding male ptarmigan and concluded they cannot be censused in small areas alone (size of their multiple study sites ranged from 3.0 to $13.5 \mathrm{~km}^{2}$ ) as the results were too variable. Others (Brodsky and Montgomerie 1987; Cotter 1999; Watson et al. 2000; Favaron et al. 2006; Pedersen et al. 2012) used methods such as marking and reobservation, point transects, and distance sampling to estimate changes in population size. Bart et al. (2011) experimented with use of helicopter and fixed-wing aircraft to survey ptarmigan (and other species) over large areas in northern Canada and Alaska. All of these methods are either labour intensive and/or costly.

The Breeding Bird Survey protocol was developed in the early 1960 s to estimate population trends in bird populations over time across large areas and variable habitats in North America (Bystrak 1981; Robbins et al. 1986; Droege 1990). It initially used 3-minute count intervals along routes with 50 stops at $0.8 \mathrm{~km}$ intervals with routes being surveyed once each year, during the breeding period. More recently 5-minute point counts have been used to better represent population indices of selected species (Ralph et al. 1995). All birds (males and females) both seen and heard are recorded at point-count stops.

Male Rock Ptarmigan during the breeding period (late April to early June) are conspicuous (they can range in colour from white to mottled shades of light brown to almost black [Attu] with white bellies and wings), perch up, and make flights from conspicuous sites while calling as they advertise and defend territories (Holder and Montgomerie 1993; Pelletier and Krebs 1997). Males in late May and early June can be solitary or paired with females, which are drab brown (in flight they have white wings) or mottled and inconspicuous in many, if not most, situations (some may be on nests).

Our objectives were to review the available literature on surveys of Rock Ptarmigan on three islands in the Western Aleutian Islands and develop and implement a 5-minute point count protocol to estimate trends in breeding populations of Rock Ptarmigan on Adak, Amchitka, and Attu islands in the Western Aleutian Islands (Figure 1).

\section{Study Area}

We reviewed the published and other available literature on Rock Ptarmigan (no other species of ptarmigan occur on these islands) on Adak $\left(51.883^{\circ} \mathrm{N}\right.$, $\left.176.65^{\circ} \mathrm{W}\right)$, Amchitka (51.35 ${ }^{\circ}-51.65^{\circ} \mathrm{N}, 178.617^{\circ}-$

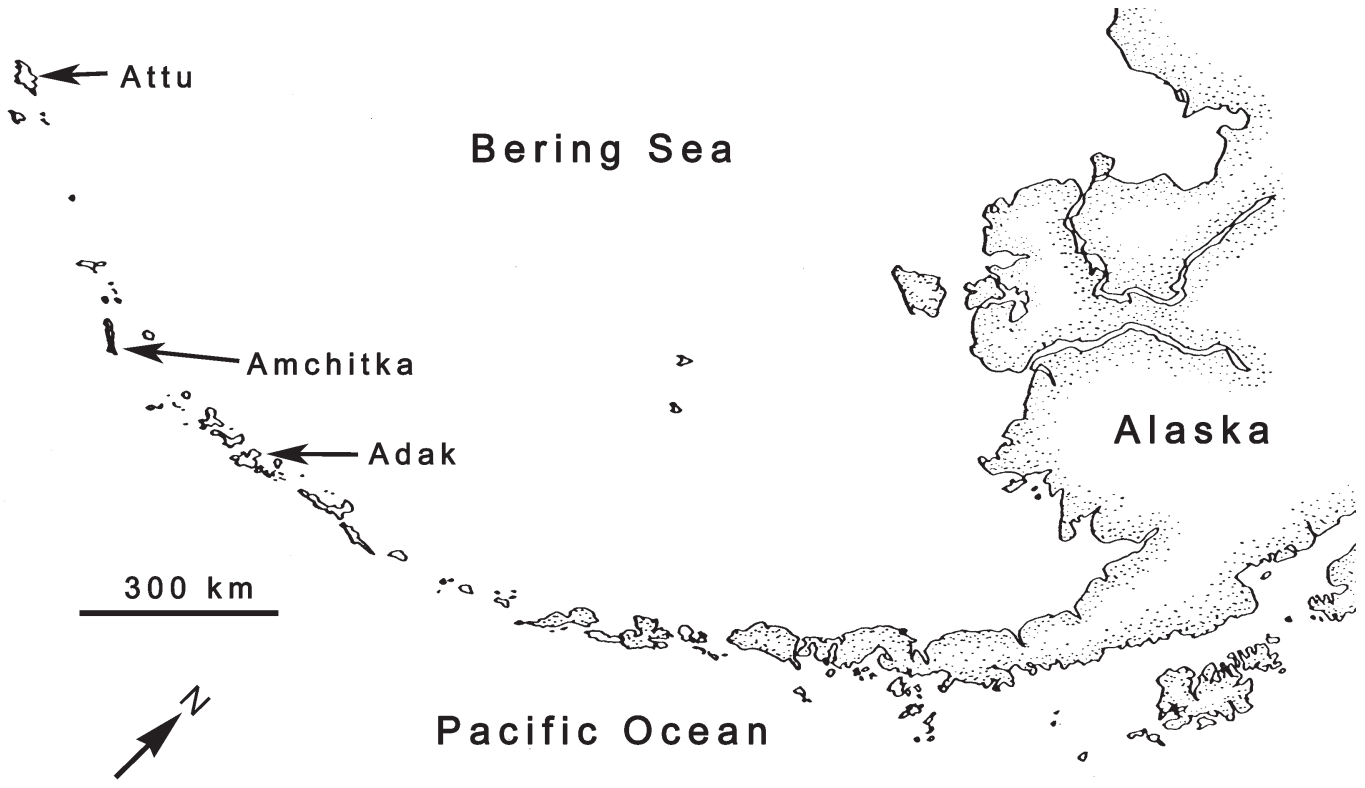

Figure 1. Aleutian Archipelago, Alaska showing Adak, Amchitka, and Attu islands. 
$\left.179.483^{\circ} \mathrm{E}\right)$, and Attu $\left(52.85^{\circ} \mathrm{N}, 173.183^{\circ} \mathrm{E}\right)$ in the Western Aleutian Islands, Alaska (Appendix S1). Areas surveyed on the three islands by us and others were similar low elevation sites (i.e., marine and stream terraces) adjacent to rarely-used trails (Amchitka and Attu) and occasionally used roads (Adak) that tended to follow coastal areas. The islands vary in size from $300 \mathrm{~km}^{2}$ (Amchitka) to $711 \mathrm{~km}^{2}$ (Adak) and $894 \mathrm{~km}^{2}$ (Attu). Adak is in the Andréanof group while Amchitka is in the Rat Island group and Attu is in the Near Islands. All are bounded by the North Pacific Ocean to the south and west and the Bering Sea to the north and east. The three islands are distant from each other with Amchitka being $301 \mathrm{~km}$ southwest of Adak that is $720 \mathrm{~km}$ east of Attu. There are no human residents on Amchitka and Attu and the resident population on Adak is variable and $<100$ people.

The geology of the three islands is complex with multiple inactive volcanos and volcanic flows as well as past glacial and marine erosion (Coats 1956; Fraser and Snyder 1959; Powers et al. 1960). Topography varies from gently sloping marine terraces to undulating tundra ranging to rugged mountains. We surveyed ptarmigan at an elevation of 10 to $300 \mathrm{~m}$ on all three islands. Lower and well-drained sites are occupied by grasses and sedges (Calamagrostis spp., Leymus spp., Carex spp.), and low-growing forbs including Caltha spp., Ranunculus spp., and Lupinus spp. with higher slopes dominated by crowberry (Empetrum spp.), Empetrum-Cladonia tundra, Cladina spp. lichens, and other mosses with some low-growing heather
(Cassiope spp., Phyllodoce spp.), willow (Salix spp.), and Kamchatka Rhododendron (Rhododendron camtschaticum Pallas) shrubs (Amundsen and Clebsch 1971; Everett 1971; White et al. 1977).

The climate on all three islands is moist marine with frequent high velocity winds, rain, and fog (Gates et al. 1971). Mean daily average temperatures vary seasonally ranging from $0.4^{\circ} \mathrm{C}$ in January to $11^{\circ} \mathrm{C}$ in August. Daily $\left(3.9^{\circ} \mathrm{C}\right.$ in all seasons) and seasonal $\left(9.4^{\circ} \mathrm{C}\right)$ ranges in temperature are limited (Armstrong 1971, 1977). Wind speeds are highly variable, and the mean annual precipitation ranges from 83 to $139 \mathrm{~cm}$, depending on the island, with June and July being the months with lowest precipitation (Weatherbase 2015).

\section{Methods}

We established and conducted 5-minute point stations (protocol in Table 1) in 2015 following Ralph et al. (1995) at $0.8 \mathrm{~km}$ intervals along trails and roads on all three islands (dates in Table 2). All routes were conducted using an all-terrain vehicle. Starting points were at trail junctions or easily recognized local features and were recorded as global positioning system coordinates (on file with Alaska Maritime National Wildlife Refuge, Homer, Alaska, USA). Point-count routes were in areas where at least four stops at $0.8 \mathrm{~km}$ intervals could be established. There were four routes on Adak with from six to 17 stops, three routes on Amchitka with from four to 21 stops, and three routes with from four to seven stops on Attu (Table 2).

TABLE 1. Protocol for Rock Ptarmigan (Lagopus muta) surveys on Adak, Amchitka, and Attu islands, Western Aleutians, Alaska.

5-minute point counts

Count and record all Rock Ptarmigan seen (as male or female) or heard at each point stop. Rarely, the vehicle stopped near a ptarmigan which did not call or flush during the 5-minute count but flushed when the vehicle departed. These birds were included in the count.

Use of two counters is best (one front and one back). A central spot should be chosen.

Consolidate and record totals at end of each point count before returning to the vehicle.

Conduct point-count route prior to 10:00 AM.

Try to avoid high winds ( $>30 \mathrm{~km}$ per hr) and heavy rain.

Adak (use GPS locations at $>0.8 \mathrm{~km}$ points)

Old Loran Road (10 stops).

Finger Cove (six stops).

Navfac Creek to past Clam Cove (17 stops).

Lake Andrew (six stops).

Amchitka (use GPS locations at $>0.8 \mathrm{~km}$ points)

Jones Lake/Engineer Road (17 stops).

Charlie-Baker Taxiway south (four stops).

Infantry Road (21 stops).

Attu (use GPS locations at $>0.8 \mathrm{~km}$ points)

Casco Cove to old airstrips (four stops).

Engineer Hill (top towards Peace monument) from Massacre Creek Beach Trail (seven stops).

Navytown (two stops) to Quonset Valley (four stops). 
TABle 2. Point-count (5-minute) surveys of Rock Ptarmigan (Lagopus muta; RP) on Adak, Amchitka, and Attu islands, Alaska, 2015-2017.

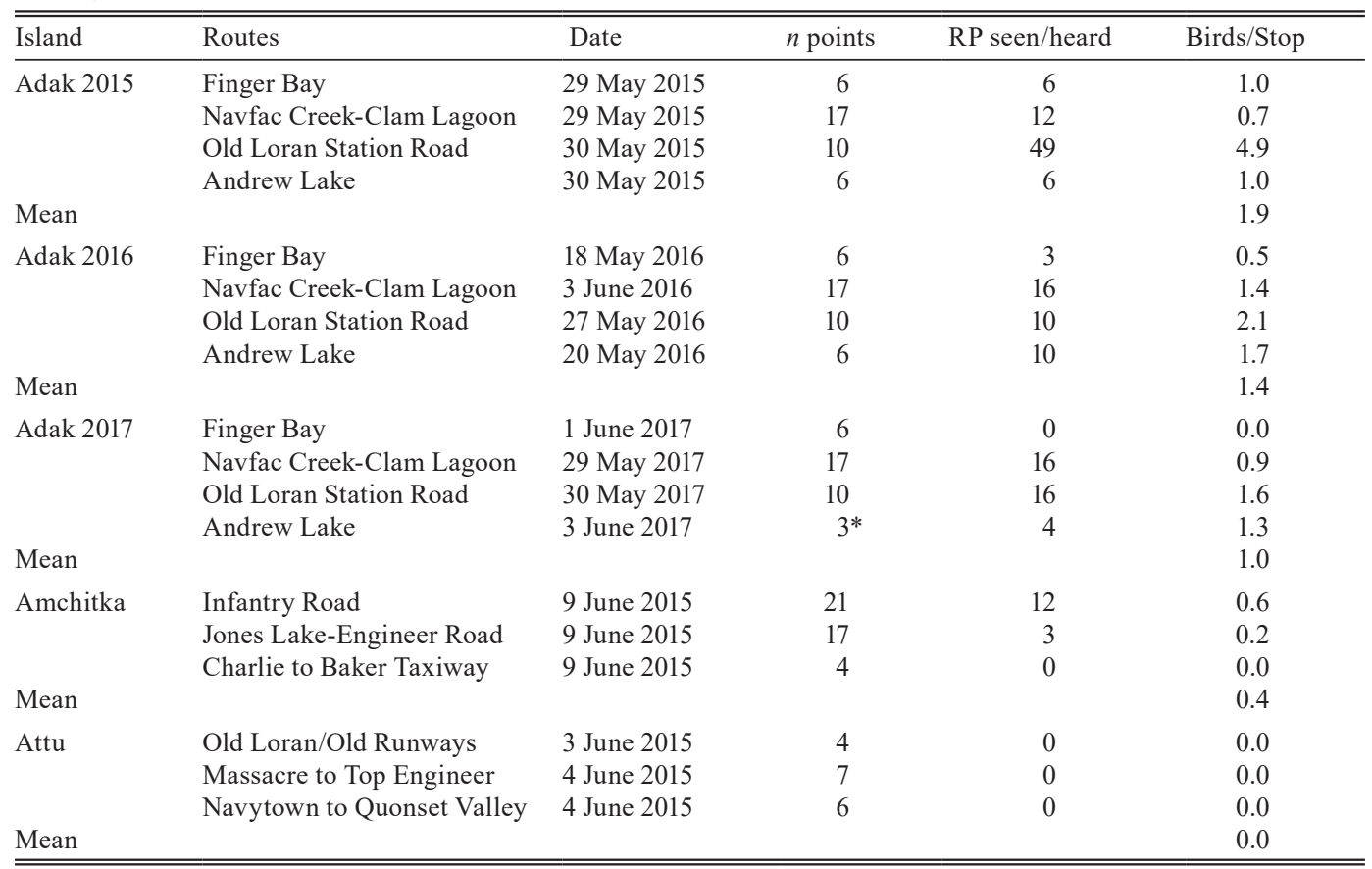

*High winds did not allow completion or resurveys of three of six routes.

\section{Results}

Rock Ptarmigan were heard or seen on all but one (2017 only) point-count routes on Adak and two of three on Amchitka but none was recorded on any of the three point-count routes on Attu (Table 2). However, one ptarmigan pair was seen and four males were heard prior to establishment of pointcount routes but not near any of the point-count stops on Attu. Numbers of ptarmigan per stop recorded on point-count routes were highest $(1.9,1.4,1.0 ; 2015-$ 2017, respectively) on Adak, lower (0.4) on Amchitka, and non-existent (0.0) on Attu.

\section{Discussion}

A literature review of surveys and reports of Rock Ptarmigan on Adak, Amchitka, and Attu Islands revealed that Rock Ptarmigan were mentioned but that few surveys occurred over time with the exception of Amchitka with less information for Attu and Adak (Appendix S1). Large populations were documented for Amchitka (White et al. 1977) and Attu (Braun et al. 2014) over short periods. Overall, the literature suggests populations of Rock Ptarmigan on the three islands were historically low, especially on Attu.

Our point counts indicate the Rock Ptarmigan population was highest on Adak (2015-2017), lower in 2015 on Amchitka, and very low on Attu in 2015. Our point-count survey data on Attu in 2015 con- firmed the ongoing decline on this island reported by Braun et al. (2014) from an intensive survey area conducted in 2003-2009. No effort was made to quantify ptarmigan numbers on Attu at higher elevations but ptarmigan were common at lower elevations in 20032005 (Braun et al. 2014).

The areas that we surveyed on all three islands had similar relief (low marine and stream terraces), were highly disturbed in the mid 1940s and 1950s (Amchitka and Attu) to the late 1990s (Adak), but are now well vegetated with low to non-existent recent human occupation. The three islands have similar predator assemblages (no ground mammals except rats, but with eagles, falcons, gulls, jaegers, owls, and ravens), but we have no estimate of densities. We have no basis to expect that predators (Gilg et al. 2003; Therrien et al. 2014) affected ptarmigan numbers on the three islands in 2015. We also detected no evidence that male aggressive behaviour was a factor at the densities we observed (Mougeot et al. 2003). The possibility that herbivory (Sinclair et al. 1988) could affect populations of ptarmigan across islands at substantial distances from each other through plant compounds was considered but was deemed unlikely because of isolation, few deciduous shrubs, and distances involved.

We documented three different levels of abundance of Rock Ptarmigan on Adak (high), Amchitka 
(lower), and Attu (very low) in 2015. The apparent, long-term decline on Attu since 2003 (Braun et al. 2014) appears to have stabilized from 2009 to 2014 (Braun et al. 2014). We agree with the hypothesis of Sandercock et al. (2005) that animal cycles in Arctic marine and terrestrial environments are most likely affected by latitudinal gradients in the north and altitudinal gradients elsewhere. The islands we studied are surrounded by the North Pacific Ocean and the Bering Sea and we worked at or below $300 \mathrm{~m}$, thus the birds on these high latitude islands are mostly affected by the marine environment. We further agree that systematic surveys (Tesar et al. 2016) to detect trends in breeding populations (Nichols and Williams 2006) of different populations of Rock Ptarmigan are needed at least at 3-5 year intervals for both theoretical and practical reasons and should be able to detect population changes. It is possible that further translocations, similar to the one from Attu to Agattu in 2003-2005 (Kaler et al. 2010), may be considered to re-establish populations where they were extirpated by introduced Arctic Fox (Vulpes lagopus). Braun et al. (2014) documented the immediate recovery of ptarmigan after removal of Arctic Fox. But before such future translocations can be considered, a better survey protocol was needed to determine population status and trends of ptarmigan on these other islands. Knowing when ptarmigan populations may be 'high', especially if they cycle, also would be important so adequate numbers can be captured for immediate release on islands currently unoccupied by Rock Ptarmigan. This should reduce costs and improve chances for success of the transplants. Understanding fluctuations of Rock Ptarmigan populations, if they occur, is also important in the Arctic as the results from studies on islands may have relevance to 'cycles' and management of species of ptarmigan in mainland areas.

Point counts may be the most efficient and least expensive method to obtain standardized data (all birds seen and/or heard) for Rock Ptarmigan in areas with road or trail systems because large areas can be surveyed with few personnel. Early counts (May) should provide an opportunity to record more females than counts in early to mid June when females will be nesting. The three islands of Adak, Amchitka, and Attu each have different Rock Ptarmigan subspecies of conservation importance (Pruett et al. 2010) and their population dynamics deserve further study. There is a continuing need for population data to provide insight into whether cycles exist and their periodicity and synchronicity among islands.

\section{Author Contributions}

Conceptualization: C.E.B., W.P.T., and S.M.E.; Funding Acquisition: S.M.E.; Investigation: C.E.B.,
W.P.T., S.M.E., and L.M.S.; Writing - Original Draft: C.E.B; Writing - Review \& Editing: C.E.B., W.P.T., S.M.E., and L.M.S.

\section{Acknowledgements}

We thank the crew of U.S. Fish and Wildlife Service research ship Tiglax for safe transit along the North Pacific Ocean and the Bering Sea and especially the administrators of the Alaska Maritime National Wildlife Refuge for support of our efforts over a period of years. We acknowledge the help of the reviewers and the Editor for improvements in the manuscript. The findings and conclusions in this article are those of the author(s) and do not necessarily represent the views of the U.S. Fish and Wildlife Service.

\section{Literature Cited}

Amundsen, C.C., and E.E.C. Clebsch. 1971. Dynamics of the terrestrial ecosystem vegetation of Amchitka Island, Alaska. Bioscience 21: 619-623. https://doi.org/ $10.2307 / 1295734$

AOU (American Ornithologists' Union). 1957. Checklist of North American birds. Fifth Edition. American Ornithologists' Union, Washington, DC, USA.

Armstrong, R.H. 1971. Physical climatology of Amchitka Island, Alaska. Bioscience 21: 607-609. https://doi.org/ $10.2307 / 1295730$

Armstrong, R.H. 1977. Weather and climate. Pages 5358 in The Environment of Amchitka Island. Edited by M.L. Merritt and R.G. Fuller. U.S. Energy Research and Development Administration, TID-26712. U.S. Department of Energy, Washington, DC, USA.

Bart, J., M. Fuller, P. Smith, and L. Dunn. 2011. Use of large-scale, multi-species surveys to monitor Gyrfalcon and ptarmigan populations. Pages 263-271 in Gyrfalcons and Ptarmigan in a Changing World. Edited by R.T. Watson, T.J. Cade, M. Fuller, G. Hunt, and E. Potapov. The Peregrine Fund, Boise, Idaho, USA. Accessed 2 March 2018. http://www.peregrinefund.org/ subsites/conference-gyr/proceedings/.

Braun, C.E., W.P. Taylor, and S.M. Ebbert. 2014. Changes in Evermann's Rock Ptarmigan density on an eastern portion of Attu Island, Alaska, 2003-2009. Northwestern Naturalist 95: 28-34. https://doi.org/10. 1898/NWN13-10.1

Brodsky, L.M., and R.D. Montgomerie. 1987. Asymmetrical contests in defence of Rock Ptarmigan territories. Behavioral Ecology and Sociobiology 21: 267-272. https://doi.org/10.1007/bf00292508

Bystrak, D. 1981. The North American breeding bird survey. Studies in Avian Biology 6: 34-41.

Cattadori, I.M., D.T. Haydon, and P.J. Hudson. 2005. Parasites and climate synchronize Red Grouse populations. Nature 433: 737-740. https://doi.org/10.1038/nature 03276

Coats, R.R. 1956. Geology of northern Adak Island, Alaska. U.S. Department of the Interior, Geological Survey Bulletin 1028-C. U.S. Government Printing 
Office, Washington, DC, USA. Accessed 2 March 2018. https://pubs.usgs.gov/bul/1028c/report.pdf.

Cotter, R.C. 1991. Population attributes and reproductive biology of Rock Ptarmigan (Lagopus mutus) in the central Canadian Arctic. M.Sc. thesis, University of Alberta, Edmonton, Alberta, Canada.

Cotter, R.C. 1999. The reproductive ecology of Rock Ptarmigan (Lagopus mutus) in the central Canadian Arctic. Arctic 52: 23-32. https://doi.org/10.14430/arctic 906

Dobson, A.P., and P.J. Hudson. 1992. Regulation and stability of a free-living host-parasite system: Trichostrongylus tenuis in Red Grouse. II: Population models. Journal of Animal Ecology 61: 487-498. https://doi. org/10.2307/5339

Droege, S. 1990. Survey designs and statistical methods for the estimation of avian population trends. Pages 1-4 in The North American Breeding Bird Survey. Edited by J.R. Sauer and S. Droege. Biological Report 90 (1). U.S. Department of the Interior, Fish and Wildlife Service, Washington, DC, USA. Accessed 2 March 2018. https:// pubs.er.usgs.gov/publication/5230211.

EIton, C.S. 1924. Periodic fluctuations in the numbers of animals: their causes and effects. British Journal of Experimental Biology 2: 119-163. Accessed 2 March 2018. https://pdfs.semanticscholar.org/22fe/348adeffd9 2761fa5a5396a71c7820f5b8c7.pdf.

Everett, K.R. 1971. The structure and origin of the organic soil cover of Amchitka Island, Alaska. Bioscience 21: 618. https://doi.org/10.2307/1295733

Favaron, M., G.C. Scherini, D. Preatoni, G. Tosi, and L.A. Wauters. 2006. Spacing behavior and habitat use of rock ptarmigan (Lagopus mutus) at low density in the Italian Alps. Journal of Ornithology 147: 618-628. https://doi.org/10.1007/s10336-006-0087-z

Fraser, G.D., and G.L. Snyder. 1959. Geology of southern Adak Island and Kagalaska Island, Alaska. U.S. Department of the Interior, Geological Survey Bulletin 1028-M. U.S. Government Printing Office, Washington, DC, USA. Accessed 2 March 2018. https://pubs.usgs. gov/bul/1028m/report.pdf.

Gates, O., H.A. Powers, and R.E. Wilcox. 1971. Geology of the Near Islands, Alaska. U.S. Department of the Interior, Geological Survey Bulletin 1028-U. U.S. Government Printing Office, Washington, DC, USA. Accessed 2 March 2018. https://pubs.er.usgs.gov/publication/b1028U.

Gibson, D.D., and B. Kessel. 1997. Inventory of the species and subspecies of Alaska birds. Western Birds 28: 4595. Accessed 2 March 2018. https://www.westernfield ornithologists.org/archive/V46/46(2)-p094-p185.pdf.

Gilg, O., I. Hanski, and B. Sittler. 2003. Cyclic dynamics in a simple vertebrate predator-prey community. Science 302: 866-868. https://doi.org/10.1126/science. 1087509

Holder, K., and R. Montgomerie. 1993. Rock Ptarmigan (Lagopus mutus). In The Birds of North America, No. 51. Edited by A. Poole and F. Gill. Academy of Natural Sciences, Philadelphia, Pennsylvania, USA.

Hudson, P.J., D. Newborn, and A.P. Dobson. 1992. Regulation and stability of a free-living host-parasite system: Trichostrongylus tenuis in Red Grouse. I: Monitoring and parasite reduction experiments. Journal of Animal
Ecology 61: 477-486. https://doi.org/10.2307/5339

Kaler, R.S.A., S.M. Ebbert, C.E. Braun, and B.K. Sandercock. 2010. Demography of a reintroduced population of Evermann's Rock Ptarmigan in the Aleutian Islands. Wilson Journal of Ornithology 122: 1-14. https://doi.org/10.1676/08-099.1

Magnússon, K., J. Brynjarsdóttir, and Ó.K. Nielson. 2004. Population cycles in Rock Ptarmigan Lagopus muta: modelling and parameter estimation. RH-19-2004, Raunvísindastofnun Háskólans, Iceland.

Montgomerie, R., and K. Holder. 2008. Rock Ptarmigan (Lagopus muta). In The Birds of North America. Edited by A.F. Poole. Cornell Laboratory of Ornithology, Ithaca, New York, USA. https://doi.org/10.2173/bna.51

Mougeot, F., S.M. Redpath, F. Leckie, and P.J. Hudson. 2003. The effect of aggressiveness on the population dynamics of a territorial bird. Nature 421: 737-739. https:// doi.org/10.1038/nature01395

Nichols, J.D., and B.K. Williams. 2006. Monitoring for conservation. Trends in Ecology \& Evolution 21: 668673. https://doi.org/10.1016/j.tree.2006.08.007

Pedersen, A.O., B.-J. Bardsen, N.G. Yoccoz, N. Lecomte, and E. Fuglei. 2012. Monitoring Svalbard Rock Ptarmigan: distance sampling and occupancy modeling. Journal of Wildlife Management 76: 308-316. https:// doi.org/10.1002/jwmg. 276

Pedersen, A.O., O. Overrein, S. Unander, and E. Fuglei. 2005. Svalbard Rock Ptarmigan (Lagopus mutus hyperboreus): a status report. Rapportserie No. 125, Norwegian Polar Institute, Tromso, Norway. Accessed 2 March 2018. http://hdl.handle.net/11250/173200.

Pelletier, L., and C.J. Krebs. 1997. Line-transect sampling for estimating ptarmigan (Lagopus spp.) density. Canadian Journal of Zoology 75: 1185-1192. https://doi. org/10.1139/z97-141

Powers, H.A., R.R. Coats, and W.H. Nelson. 1960. Geology of and submarine physiology of Amchitka Island, Alaska. U.S. Department of Interior, Geological Survey Bulletin 1028-P. U.S. Government Printing Office. Washington, DC, USA. Accessed 2 March 2018. https://pubs.usgs.gov/bul/1028p/report.pdf.

Pruett, C.L., T.N. Turner, C.M. Topp, S.V. Zagrebelny, and K. Winker. 2010. Divergence in an archipelago and its conservation consequences in Aleutian Island Rock Ptarmigan. Conservation Genetics 11: 241-248. https:// doi.org/10.1007/s10592-009-0026-7

Ralph, C.J., S. Droege, and J.R. Sauer. 1995. Managing and monitoring birds using point counts: standards and applications. Pages 161-170 in Monitoring Bird Populations by Point Counts. Edited by C.J. Ralph, J.R. Sauer, and S. Droege. U.S. Department of Agriculture, Forest Service, Pacific Southwest Research Station General Technical Report PSW-GTR-149. Albany, California, USA. Accessed 2 March 2018. https://www.fs. fed.us/ psw/publications/documents/gtr-149/pg161_168.pdf.

Robbins, C.S., D. Bystrak, and P.H. Geissler. 1986. The Breeding Bird Survey: its first fifteen years, 1965-1979. U.S. Department of the Interior, Fish and Wildlife Service Resource Publication 157. Accessed 2 March 2018. https://pubs.er.usgs.gov/publication/5230189. 
Sandercock, B.K., K. Martin, and S.J. Hannon. 2005. Life history strategies in extreme environments: comparative demography of Arctic and alpine ptarmigan. Ecology 86: 2176-2186. https://doi.org/10.1890/04-0563

Sinclair, A.R.E., C.J. Krebs, J.N. Smith, and S. Boutin. 1988. Population biology of snowshoe hares. III. Nutrition, plant secondary compounds and food limitation. Journal of Animal Ecology 57: 787-806. https://doi. org/10.2307/5093

Taylor, W.P. 2013. Status of upland game within Alaska's highway system: a comprehensive report focusing on 2007-2011. Wildlife Management Report, ADF\&G/ DWC/WMR-2013-1. Alaska Department of Fish and Game, Division of Wildlife Conservation, Palmer, Alaska, USA. Accessed 12 August 2015. https://www.adfg. alaska.gov/static/research/programs/smallgame/pdfs/ upland_game_status_2007_2011.pdf.

Tesar, C., M.-A. Dubois, and A. Shestakov. 2016. Toward strategic, coherent, policy-relevant Arctic science. Science 353 (6306): 1368-1370. https://doi.org/10.1126/ science.aai 8198

Therrien, J.F., G. Gauthier, E. Korpimäki, and J. Bêty. 2014. Predation pressure by avian predators suggests summer limitation of small-mammal populations in the Canadian Arctic. Ecology 95: 56-67. https://doi.org/10.
1890/13-0458.1

Watson, A. 1965. A population study of ptarmigan (Lagopus mutus) in Scotland. Journal of Animal Ecology 34: 135172. https://doi.org/10.2307/2373

Watson A., R. Moss, and P. Rothery. 2000. Weather and synchrony in 10-year population cycles of Rock Ptarmigan and Red Grouse in Scotland. Ecology 81: 21262136. https://doi.org/10.1890/0012-9658(2000)081[2126: wasiyp]2.0.co;2

Weatherbase. 2015. Travel weather averages for Adak, Alaska, USA. Accessed 12 August 2015. http://www. weatherbase.com/adak

Weeden, R.B. 1965. Breeding density, reproductive success and mortality of Rock Ptarmigan at Eagle Creek, central Alaska from 1960-1964. Transactions of the North American Wildlife Conference 30: 336-348.

White, C.M., F.S.L. Williamson, and W.B. Emison. 1977. Avifaunal investigations. Pages 227-260 in The Environment of Amchitka Island. Edited by M.L. Merritt and R.G. Fuller. U.S. Energy Research and Development Administration, TID-26712. U.S. Department of Energy, Washington, DC, USA.

Received 3 May 2017

Accepted 6 February 2018

\section{Supplementary Material:}

Appendix S1. Historical review of information and previous studies and surveys for Rock Ptarmigan (Lagopus muta) on three islands (Adak, Amchitka, and Attu) in the Western Aleutian Islands in Alaska. 